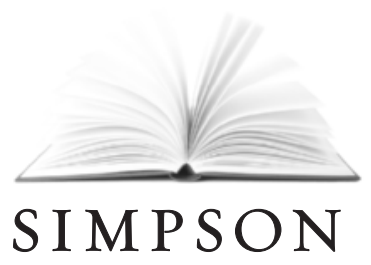

I M P RINT IN HUMANITIES

The humanities endowment

by Sharon Hanley Simpson and

Barclay Simpson honors

MURIEL CARTER HANLEY

whose intellect and sensitivity

have enriched the many lives

that she has touched. 
This page intentionally left blank 


\section{Printer's Devil}


The publisher gratefully acknowledges the generous contribution to this book provided by the Simpson Humanities Endowment Fund of the University of California Press Foundation. 


\title{
Printer's Devil
}

MARK TWAIN AND THE AMERICAN

PUBLISHING REVOLUTION

\author{
Bruce Michelson
}

甲

UNIVERSITY OF CALIFORNIA PRESS

BERKELEY LOS ANGELES LONDON 
University of California Press, one of the most distinguished university presses in the United States, enriches lives around the world by advancing scholarship in the humanities, social sciences, and natural sciences. Its activities are supported by the UC Press Foundation and by philanthropic contributions from individuals and institutions. For more information, visit www.ucpress.edu.

University of California Press

Berkeley and Los Angeles, California

University of California Press, Ltd.

London, England

(C) 2006 by The Regents of the University of California

Library of Congress Cataloging-in-Publication Data

Michelson, Bruce, 1948-

Printer's devil : Mark Twain and the American publishing revolution / Bruce Michelson.

p. $\quad \mathrm{cm}$.

Includes bibliographical references and index.

ISBN-I3 978-0-520-24759-8 (acid-free paper)

ISBN-IO O-520-24759-O (acid-free paper)

I. Twain, Mark, I835-1910-Knowledge-Printing. 2. Printing in literature. 3. Printing-United StatesHistory-I9th century. 4. Publishers and publishingUnited States-History-19th century. 5. Authors and publishers-United States-History-Igth century.

I. Title.

PSI342.P67M53 2006

$818^{\prime} .409-\mathrm{dc} 22$ 2005034481

Manufactured in the United States of America

$\begin{array}{llllllllll}\text { I5 } & \text { I4 } & \text { I3 } & \text { I2 } & \text { II } & \text { IO } & 09 & 08 & 07 & 06\end{array}$

$\begin{array}{llllllllll}\text { IO } & 9 & 8 & 7 & 6 & 5 & 4 & 3 & 2 & \text { I }\end{array}$

This book is printed on New Leaf EcoBook 50, a 100\% recycled fiber of which $50 \%$ is de-inked post-consumer waste, processed chlorine-free. EcoBook 50 is acid-free and meets the minimum requirements of ANSI/ASTM D5634-OI (Permanence of Paper). 
For Barbara Elizabeth Yates 
This page intentionally left blank 